\title{
Didactics as a research laboratory for the improvement of the structure of historical inner cities
}

\author{
Eliza Szczerek ${ }^{1}$ | Anna Franta ${ }^{2}$ | Bartlomiej Hominski ${ }^{3}$
}

Received: 2020-01-21 | In its final version: 2020-07-07

Abstract

Nowadays the notion of the historical centre of cities no longer refers only to valuable historical areas, nor to 19th-century districts surrounding them. The notion of a historical centre can, and in fact should, be extended to cover structures that came into being later. Their features, such as e.g. concentration and diversity of functions, expressiveness of the urban form, presence in the awareness of city residents, favourable location, etc., provide them with the significance of local centres in a complementary relationship with the most valuable historical heart of the city. The goal of this paper is to demonstrate that it is possible to apply a properly designed didactic process in the teaching of urban design and architecture. It can serve as a tool for testing and verifying research hypotheses posed by an academic who is an architect, a researcher, and a teacher at the same time (hereinafter referred to as 'architect-researcher-teacher'). This in turn can be beneficial for applying such hypotheses in the designing practice, broadening the knowledge in the academic discipline of architecture, and opening up new fields of study. In this case, the research method and tool is a lab/design studio at the school of architecture. The authors - architects-researchers-teachers themselves - took up research issues in the urban and architectural scale in their teaching process, which were of key importance for the improvement of historically formed inner-city structure. The authors' experiences presented in this paper prove that a properly directed teaching process in urban planning and architecture allows effectively testing and verifying research hypotheses posed by the architect-researcher-teacher, to enrich the academic field of architecture, always with the element of designing, which is of key importance.

Key words: Extension of historical centre's notion; development through improvement; design studio as a research laboratory

Citation

Szczerek, E. et al. (2020). Didactics as a research laboratory for the improvement of the structure of historical inner cities. ACE: Architecture, City and Environment, 15(44), 9197. DOI: http://dx.doi.org/10.5821/ace.15.44.9197

\begin{abstract}
1 Ph.D. Arch., Assistant Professor, Faculty of Architecture, Cracow University of Technology (ORCID ID: $\underline{0000-}$ 0002-2787-7334, WOS Researcher ID: ABB-3737-2020, Scopus Author ID: 57207470342). ${ }^{2}$ D.Sc. Ph.D. Arch. Architect, Associate Professor, Faculty of Architecture, Cracow University of Technology (ORCID ID: $\underline{0000-}$ 0001-6351-8622, wOS Researcher ID: ABB-5790-2020, Scopus Author ID: 57207457153). ${ }^{3}$ Ph.D. Arch., Assistant Professor, Faculty of Architecture, Cracow University of Technology (ORCID ID: 0000-00023509-2078, WOS Researcher ID: ABB-3370-2020, Scopus Author ID: 57207295701). Contact e-mail: eszczerek@pk.edu.pl
\end{abstract}

ACE, 15 (44) CC BY-ND 3.0 ES | UPC Barcelona, España $\mid$ Didactics as a research laboratory for the improvement of the structure of historical inner cities. DOI: http://dx.doi.org/10.5821/ace.15.44.9197 


\section{Introduction}

"Cities are a product of time"

(Mumford, 1970, p. 4)

The concept of sustainable development, which has dominated the approach to the city since the late $20^{\text {th }}$ century, inclines to a revision of the way of thinking about the development of cities. It evolves from the approach consisting in the territorial sprawl to the one leading towards the improvement of the already existing urban structures, as an environmentally and socially more efficient strategy of urban development (Gzell, 2015).

The concern of municipal authorities and city dwellers, but also the interest of investors, resides in previously developed areas, such as post-war block development estates, areas with overgrown technical and traffic infrastructure, or abandoned industrial plants and warehouses, which exhibit a particularly high potential of development through improvement by means of an overall strategy of functional and spatial transformations.

The notion of the historical centre of cities extends. It no longer refers only to valuable historical areas, nor to $19^{\text {th }}$-century districts surrounding them, an effect of the territorial expansion of cities associated with the beginnings of industrialisation and massive inflow of people to cities. The notion of a historical centre can, and in fact should, be extended to cover structures that came into being later. Their features, such as e.g. concentration and diversity of functions, expressiveness of the urban form, presence in the awareness of city residents, favourable location, etc., provide them with the significance of local centres in a complementary relation with the most valuable historical heart of the city. The significance of the historical centre in a broader sense of the urban context is reflected in the following thought: "The heart corresponded to the centre, and the various parts of the body corresponded to various functions in the city, [...] This heart-centre is, therefore, at once the centre of life and the centre of intelligence that emanates from the centre to all the parts of the body" (Nasr, 2001, pp. 17-18).

This heart, however, due to its uniqueness, is often burdened beyond measure with both tourist traffic and all sorts of occasional activities, not always adequate to the character of a particular place, and most of all to its cultural value. More and more often, public spaces of historical city centre need support. This can be provided by new public spaces of much lower historical attractiveness, but connected with them into a continuous system and easily accessible for pedestrians, cyclists, or users of public transport. This gives a chance to extend the functional possibilities and offer a new spatial typology, quite impossible to be applied in the most valuable historical areas. This also corresponds with an idea of retrofits into the historic fabric, leading to strengthening the ties between city centres and their outer boroughs (Busquets, 2006).

The topic of historical centres and the challenges they face is the subject matter of research the verification of which calls for studies based on designing methodology for the implementation measures to be effective and safe. In the cases discussed in the paper, the authors - architectsresearchers-teachers - took up research issues in the urban and architectural scale in their teaching process, which were of key importance for the improvement of historically formed inner city structure.

The goal of this paper is to demonstrate that it is possible to apply a properly designed didactic process in the teaching of urban design and architecture. It can serve as a tool for testing and verifying research hypotheses posed by an academic who is an architect, a researcher, and a teacher at the same time. This in turn can be beneficial for applying such hypotheses in the designing practice,

ACE, 15 (44.) CC BY-ND 3.0 ES | UPC Barcelona, España | Didactics as a research laboratory for the improvement of 
broadening the knowledge in the academic discipline of architecture, and opening up new fields of study to respond to the fast-changing world (Spiridonidis \& Voyatzaki, 2017).

In this case, the research method and tool is a lab / design studio at the school of architecture. In the conditions of the academia, despite certain limitations (students' previous preparation and level of skills), it is possible to verify a specific design task in quite a few variants in a process that usually lasts one semester. In professional practice and in the process of implementing decisions of local authorities, it is usually impossible for procedural, financial, and time-related reasons.

\section{Usefulness of "didactic laboratory" in research of historical inner cities problems}

\subsection{Continuity and complementarity of public space in the scale of the city}

The first of such research issues of key importance for historical inner cities is the development of the continuity of the public space in the scale of the city. What is crucial in this respect is neutralisation of urban barriers, as well as taking into account relations between local centres including in particular multi-family large-panel housing estates - in the complementary relation with the most valuable historical heart of the city (Szczerek, 2017). Research on the relations between systematic revitalisation of space in large-panel housing estates and the development of continuity and complementarity of the system of public spaces of the contemporary city covers the issue of extending the notion of historical centre with appropriate support for a structure exhibiting the highest historical values.

The subject matter of this research is also in line with the tendency observed globally, consisting in transforming urbanised areas into cities and regions of culture and knowledge (Musterd, 2004; Brenner, 2005; Van Winden, 2010). It is associated with the improvement of housing estates built in the 1970s and 1980s in the large-panel technology, aimed to obtain a fully-fledged, multifunctional urban housing environment, fostering social development and consistent with the historical inner city.

The research in question refers to a number of previous studies (Jeżak, et al., 2011; Jeżak, 2006; Rowlands, et al., 2009; Van Kempen, et al., 2005; Gronostajska, 2007; Rembarz, 2009; Kovác \& Herfert, 2012; Knorr-Siedow \& Droste, 2003; Muliuolytè, 2013). It concentrates predominantly on German experiences over the last decade, and substantially on conditions fostering the appearance of a valuable public space, complementary towards the one existing in the historical inner city. The application goal is usefulness for the revitalisation of large-panel housing estates in Cracow whose potential and revitalisation-related needs and conditions are examined upon selected examples, in terms of the feedback in the relation city-estate and estate-city.

A thesis was posed that "the potential residing in the public space of large-panel housing estates, in the systematic revitalisation process aiming to obtain its attractiveness and individual character, allows to enrich and create complementarity and continuity of the system of public spaces of the city" (Szczerek, 2017, p. 11).

The sociological background - transformation of the modern society into a post-modern one along with its consequences for the public space of cities, provided a theoretical foundation for subsequent stages of the research. They comprised a multifaceted analysis of conditions, systematic solutions

ACE, 15 (44.) CC BY-ND 3.0 ES | UPC Barcelona, España | Didactics as a research laboratory for the improvement of the structure of historical inner cities. DOI: http://dx.doi.org/10.5821/ace.15.44.9197 
and revitalisation effects (inclusive of its effectiveness) of eight selected large-panel housing estates in Germany.

The next step comprised a synthetic definition of functioning conditions for large-panel housing estates in Poland (inclusive of formal and legal bases for their revitalisation at the central administration (evel), choosing as an example the situation of large-panel housing estates in Cracow and those problems of Cracow the solution of which could be accelerated by systematic revitalisation of housing estates. This in turn allowed to draw up targeted, detailed characteristics of selected housing estates in Cracow and to present methods of creating public spaces, ways of obtaining their continuity and defining the outer edge of the city - all this in the context of German revitalisation experiences.

The research results demonstrate the culture-forming significance of systematic revitalisation proven by reasoning - directed towards strengthening and creating of a new identity of housing estate complexes in the city structure, which thus complementarily supports the identity characteristic for the historical inner city. The systematic approach towards long-term and coordinated revitalisation measures that is regarded as a useful tool of creative improvement of the city structure as a whole.

The study of the German experiences and the analysis of selected Cracow-based cases demonstrate the legitimacy of a holistic approach to determining revitalisation scopes and plans basing on the system of criteria covering the most important aspects of functioning and necessary activities in the context of the current situation of housing estates and of the intended effects (Figure 1).

Figure 1. Measures leading to complementarity of public spaces of housing estates in the relation to the continuity of public spaces of the city

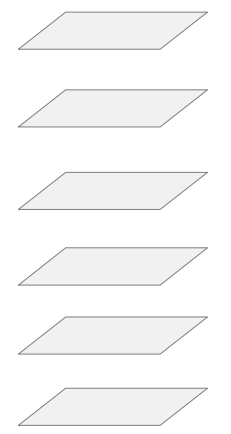

ELIMINATION OF PROBLEMS HINDERING HOUSING ESTATES FROM OBTAINING A VALUABLE HOUSING ENVIRONMENT (multifunctionality, legibility, composition, etc.)

INCLUSION OF THE HOUSING ESTATES IN THE SYSTEM OF PUBLIC SPACES OF THE CITY

IDENTIFICATION AND RECOGNITION OF THE UNIQUENESS / SPECIAL FEATURES / POTENTIAL OF THE HOUSING ESTATE (semantic layer / physical layer)

AIMING TO ACHIEVE COMPLIANCE WITH SUSTAINABLE DEVELOPMENT TENDENCIES

RECOGNITION OF CONTEMPORARY NEEDS OF THE 2OTH-CENTURY SOCIETY

REACTION TO LOCAL / SPECIFIC PROBLEMS OF A GIVEN HOUSING ESTATE

Source: Szczerek, E. (2018).

Such an approach can support not only the creation of foundations for rational planning of revitalisation processes, but also stop unfavourable tendencies, so well visible upon Cracow's example, relating to the functioning of housing estates (such as e.g. chaotic densification), causing an irreversible loss of their existing or potential values.

The analysis of the current condition of selected Cracow-based large-panel housing estates implies that it is possible to adapt the German experiences to the revitalisation of Polish housing estates. It seems possible to formulate general rules for revitalisation of such housing estates and different strategies depending on the character of a given estate, its location towards the historical inner city, taking advantage of its still existing potential.

Revitalisation of housing estates may contribute to obtaining two goals: strengthened continuity of public spaces in the city, and creation of its valuable edge, composed instead of accidental one. In

ACE, 15 (44.) CC BY-ND 3.0 ES | UPC Barcelona, España | Didactics as a research laboratory for the improvement of

the structure of historical inner cities. DOI: http://dx.doi.org/10.5821/ace.15.44.9197 
the case of Cracow, revitalisation of housing estates has a chance to contribute to e.g. strengthening of the continuity of municipal greenery, improvement of aerosanitary conditions, identification of essential cultural values of the place, and shaping of a system of public spaces of a natural and cultural character.

These results, upon the example of the Podwawelskie housing estate ${ }^{1}$ in Dębniki located the closest to the historical inner city, with numerous essential compositional relations, are depicted in the following figure.

Figure 2. Scheme of directions of building of the public space continuity and complementary in the relation Podwawelskie Estate - City

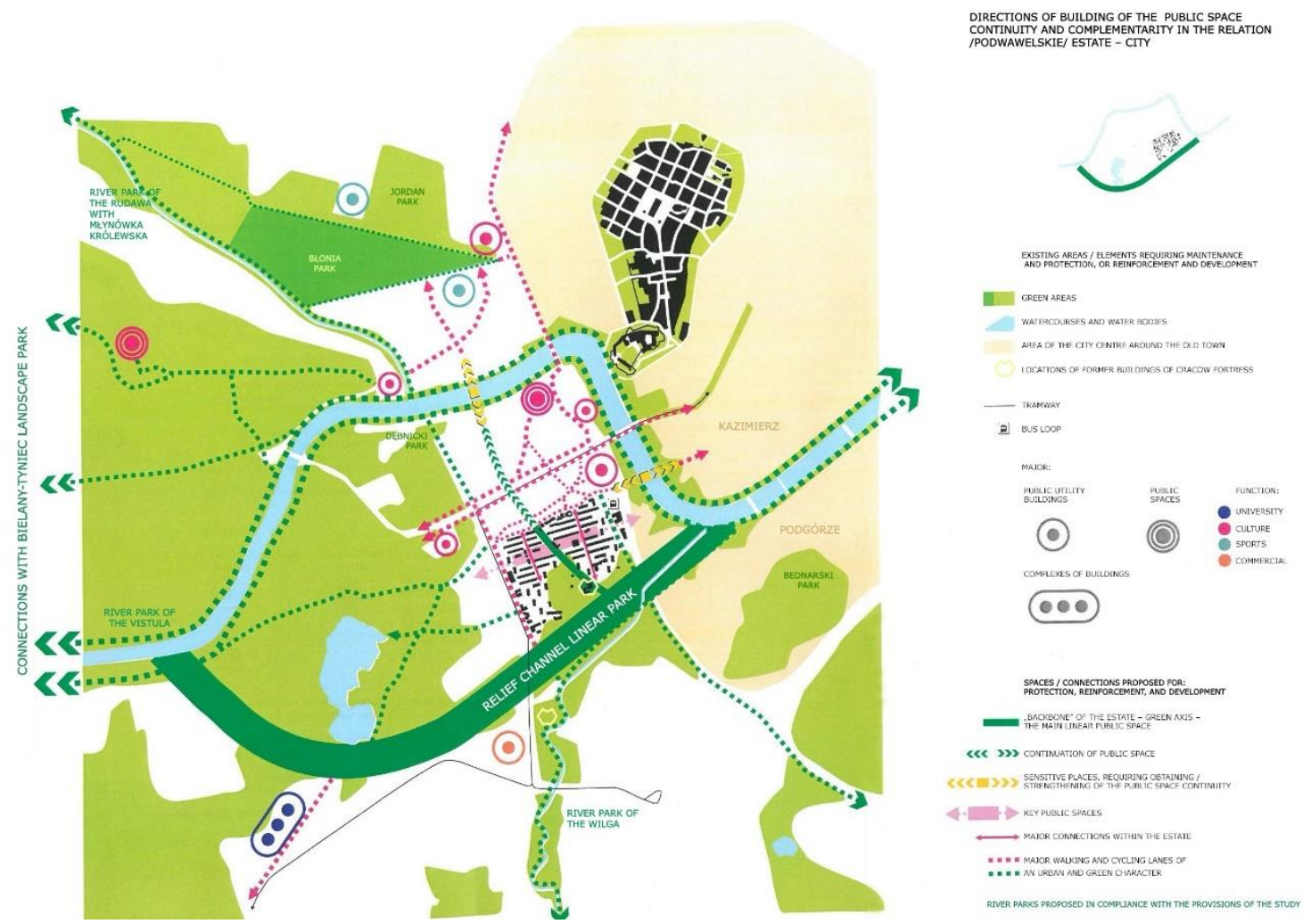

Source: Szczerek E. (2017).

The guidelines contained in this figure became a starting point for design-related verification conducted with the application of the didactic research laboratory, referred to in the introduction hereto. $3^{\text {rd }}$-year students were given a task to develop a solution that would address the provision included in the public space continuity diagram (Figure 2).

The aim was to link the Podwawelskie housing estate with the other bank of the Vistula, and further on, with the most characteristic green public space of Cracow - Błonia Park. This is in line with an idea of developing stable and continuous blue-green infrastructure of the city (Matusik, et al., 2020).

1 This housing estate was built in 1968-1974 in the industrial technology, predominantly as 5-storey buildings with many staircases and 11-storey tower blocks. Today it is inhabited by ca. 10,000 people. Distance from the Market Square: ca. $2.5 \mathrm{~km}$; distance from the Wawel Castle: $1.5 \mathrm{~km}$.

ACE, 15 (44.) CC BY-ND 3.0 ES | UPC Barcelona, España | Didactics as a research laboratory for the improvement of the structure of historical inner cities. DOI: http://dx.doi.org/10.5821/ace.15.44.9197 


\section{ACE Architecture, City and Environment}

E-ISSN 1886-4805

Figure 3. "Green ribbon of activity" - design concept of collision free continuity of public space
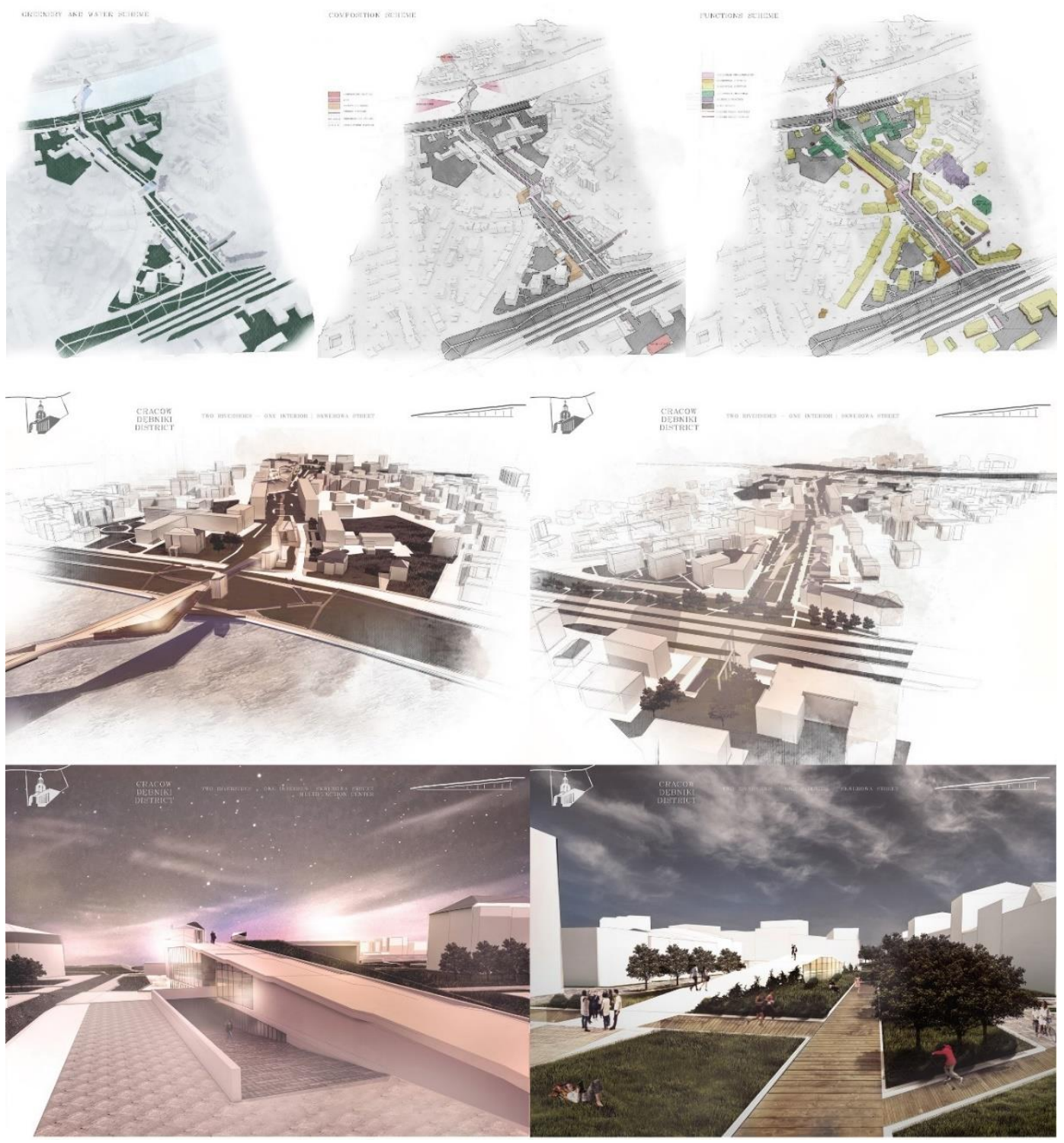

Source: Course project; author/student: Kamila Solak, Year 3, Sem.6; Supervisor: Assoc. Prof. Anna Franta, D.Sc., Ph.D., Arch.; Co-Supervisor: Eliza Szczerek, Ph.D., Arch.

The design that illustrated a possible solution² (Figure 3) proposed a linear public space of a new quality, which makes use of the already existing potential (an elongated square, the space between the buildings, and the space between the schools). By means of elimination of collision elements and improvement of the beneficial ones, favourable conditions were created for the enrichment of the layout with new functions in a new form, not applied here so far. An underground sports and entertainment complex was introduced, functionally open to both schools, along a walking lane elevated above the ground, highlighting the view of the historic sites of Cracow and linking two river banks as a living bridge. One cohesive urban interior with three functional levels came into being, bustling with activity - a pedestrian (and cycling) domain, collision free towards the local urban barriers: busy streets and the river.

2 Urban Design "Two Banks - One Interior" Debniki/Zwierzyniec; student: Kamila Solak, Year 3, Sem.6, Academic Year 2017/18; Supervisor: Assoc. Prof. Anna Franta, D.Sc., Ph.D., Arch.; Co-Supervisor: Eliza Szczerek, Ph.D., Arch. 


\subsection{Culture-forming generators of public space relieving the most valuable historical urban tissue}

The issue of continuity of public spaces is connected with another essential problem and research area, which is the search of an appropriate generator and identifier of new public spaces coming into being and relieving traditional public spaces in the most valuable tissue of historical inner cities (Gyurkovich, 2010; Węctawowicz-Gyurkovich, 2013). A particular potential in this respect resides in designing public and university libraries, corresponding to contemporary challenges resulting from the development of information technology, but also their role in the city centre structure as "elements crystallising" (Franta, 2004) the public space of a culture-forming and educational character.

The scientific goal of the conducted research (Homiński, 2011) was to recognise transformations affecting buildings of libraries in connection with societies entering the civilisation of knowledge and to determine the effect such transformations have upon the role of libraries in the city structure. The implementation goal, on the other hand, was to formulate conclusions useful for architects and all actors involved in the processes of planning, programming, designing of new libraries, as well as reconstructing and extending of the already existing facilities. The results could also be useful to the ones responsible for space management and implementation of local revitalisation programmes in cities. It was also assumed that the experience gained during the research work and the research results will be also used in the didactic work in two ways: teaching, and verification of research theses in studies devoted to possible new typologies in the checking by design procedure.

The following thesis was posed: "in the result of current civilisation transformations the significance of libraries as important public facilities in cities has been growing. Changes refer to their programme and functional structures, utilisation structures, as well as spatial relations inside buildings and their links with the surrounding tissue. Contemporary libraries can also significantly influence their neighbourhood in social terms, creating new or enriching existing public spaces and integrating communities concentrated around them" (Homiński, 2011, p. 11).

The goal of the analysis of a broad economic, spatial, and social context was to demonstrate a qualitative change, covering nearly all walks of life: work, home, and pastimes. Such transformations, which are consequences of the information technology development, have also their effect on the operation and form of libraries as public utility buildings and generators of activities which become more and more diversified. In the course of the analysis a number of phenomena were observed, constituting the background for changing the manner of operation and forms of libraries.

Whereas examination of a number of implemented libraries and of their functioning also in relation to the public space allowed to recognise the multidimensionality of the search of the formula of libraries and characteristic design-related issues depicting individual popular directions of such pursuits.

The entire research allows to formulate forecasts relating to the directions in which libraries may develop, particularly in the aspect of their relations with public spaces. Libraries shall transform from into supermarkets of information, and librarians from guardians into guides in the world of diversity. In their operation and arrangement, libraries will aim to obtain high diversity of places for work and creation of a diversified atmosphere, fostering concentration as well as relaxation, so as to meet users' expectations, different lifestyles and different preferences, including different times of activity (Hvenegaard \& Jochumsen, 2009).

ACE, 15 (44.) CC BY-ND 3.0 ES | UPC Barcelona, España | Didactics as a research laboratory for the improvement of 
Libraries will still act as places of social interaction and this mission of theirs will become more and more important. Libraries, which constitute "the social capital infreastructure", have the ability to bring communities together around them (Murzyn-Kupisz \& Działek, 2015). Due to the predicted demographic changes (aging of societies, changes in household models, migrations), libraries will be assigned tasks connected with social integration and prevention of social exclusion.

Therefore, it can be stated that libraries may remain (or become) vivid and frequented facilities in the spatial structure of cities, particularly their centres. By becoming elements of revitalisation programmes and urban designs, they can contribute to the development and blooming of their neighbourhoods (Murzyn-Kupisz \& Działek, 2013).

Libraries understood this way as important generators of traffic and popular destinations of visits may be used, therefore, as important elements of broader measures, such as revitalisation projects, despite the fact that the turn of the $20^{\text {th }}$ century brought many doubts as to the functioning of libraries. Whereas - paradoxically - the time when a printed book gives way to digital media, is also a period when the most magnificent and attractive edifices of libraries have been, and still are being, erected. It is not without a reason that the special issue of the Detail magazine, entirely devoted to libraries, opens the question of Christian Schittich, editor-in-chief: "Is it just a coincidence that some of the most spectacular library buildings are being created in the age in which the book is increasingly challenged by electronic media? Does it merely signify a final flowering of this type, or are libraries just as relevant today as at any time on their history?” (Schittich, 2005, p. 246).

Separation of the content of information from the physical carrier it is stored on, which has resulted from the development of information technology, changes the tasks of libraries. Their role of a place of collecting books becomes less important, in favour of providing and exchange of information (Bonet, 2017). Hence, libraries significantly broaden the range of the services they offer and create spaces which can concentrate many different activities crucial for the functioning of a community. The space of book collections begins to give way to the space of users.

Some new tasks of libraries also result from human needs, constituting a reaction to the progressing dominance of technology in man's life. Hence deliberations on the improvement of the life comfort in cities point to the need to once again provide contemporary man with the sense of cultural continuity and identity. The icons of public buildings and thoughts stored in books are still understood as a metaphor of permanence that man needs (Palej, 2007).

Creation, restoration, or enhancing the legibility of urban tissue continuity and creation of public space by means of the library function in its new notion - that was the objective of applying the research thesis and results presented herein in the didactic process at the stage of diploma designs. The task was to improve the existing historical tissue of the city by introducing hybrid urban structures in it, the dominating functional component of which in both cases, quite different in terms of location, was a public library in its contemporary approach.

The phenomenon of the place of exchange of goods and information was the starting point for the work on the project "Transformation in Architecture. Library - the Bazaar of Culture at Różyc in Praga, Warsaw"3 (Figure 4). Różyc as mentioned in the title is one of the best known open-air markets in Warsaw, operating since the turn of the $19^{\text {th }}$ century to date in Praga - the right-bank part of Warsaw. The destruction of the World War II affected Praga much less than the left-bank part of the Polish capital city, hence its historical urban tissue has been partially preserved here, along with the prewar landscape of local streets, residents, habits, and language. After the war, in the reality of centralised, nationalised economy of a socialist state, Różyc was an enclave of private business. It

\footnotetext{
${ }^{3}$ Author: Wojciech Szydłowski, Supervisor: Assoc. Prof. Anna Franta, D.Sc., Ph.D., Arch.; Co-Supervisor: Bartłomiej Homiński, Ph.D., Arch.; academic year 2015/2016.
}

ACE, 15 (44.) CC BY-ND 3.0 ES | UPC Barcelona, España | Didactics as a research laboratory for the improvement of 
also became a black market centre, perpetuating its prewar and war reputation of a place where one can buy and sell nearly everything. However, the significance of Różyc was much broader and it comprised other domains of social activity. It was a place where valuable information was exchanged, where one could enjoy some legal and illegal entertainment, and simply spend some time.

After the fall of the iron curtain and in the consequence of subsequent social and economic transformations, in 1989 the market started to become less important. The dilapidated Różyc market operates to date, but the foundations of its persistence are far from economic. The market is, however, an element of culture of Warsaw, and despite the fact it has lost its significance as a market place, it occupies a prominent position in the awareness of local residents. It has been a subject of interest of many researchers and designers, fascinated with the myth of Różyc (Sidorek, 2009, 106).

In the design, in compliance with the guidelines of the local plan, it was proposed to complete the quarter with mostly residential development, with services in ground floors, such as crafts and contemporary production. A number of semi-open major yards with residential and service premises have been designed, which are interconnected with a sequence of gate passages, similarly to the existing backyards of the $19^{\text {th }}$-century buildings. The city life that takes place in the backyards constitutes an element of the local folklore.

The tradition of a place of the information exchange (of an informal nature, as well) and of being informed, attached to Różyc for decades, was crucial for the decision to complete the functional programme of this quarter with public functions: a public library and a theatre space, experimental in character. The main edifice of the library is located at Brzeska street, on a part of the area occupied by the bazaar at the moment. It does not separate the bazaar from the street, though, because the library programme is elevated to the level of the first and second floor, thus releasing a section of the area and providing access to a part of the market place located in the centre of the quarter. This hybrid solution of accumulation and overlapping of the outer and inner space allowed to achieve opposing goals, i.e. to complete the frontage and to assign a sufficient plot to the library, and on the other hand to maintain access to the bazaar from Brzeska street in a place where it used to be.

The programme of the library, located on the first and second floor, is dominated by diversified places addressed to users benefitting from this space in many different ways: on their own or in groups, in silence or not, in a hidden or exposed place, facing inwards or outwards. Designing both levels with a minimum number of rooms separated with walls and the application of escalators brings to mind associations with the space of shopping galleries. Similarly, to the chain of public libraries Idea Store in Tower Hamlets in London, the distribution of individual zones of the library makes use of exposition techniques well known from commerce, in order to reduce the festive character of the library and make it more accessible to the district residents (Melvin, 2006).

The arrangement of the market place is based on a repetitive model of rectangular stalls, forming an irregular network of walking lanes. Stalls with diversified heights of platforms intended for displaying the merchandise, so that they could also serve as e.g. benches, tables, allowing to cultivate the celebration of everyday shopping, so characteristic for Różyc, as well as make use of this space also after closing the bazaar.

The hypothesis posed jointly by the supervisors and the diploma candidate assumed that the tradition of the place of goods and information exchange connected with the operation and myth of the openair market can be developed to the stage of an urban hybrid with a library function within its contemporary meaning and, consequently, to crystallisation of a public space with a culture-forming and educational character. The resultant designing concept fully confirmed the legitimacy of the assumed hypothesis and provide conditions for the traditional street life characteristic for Praga to continue.

ACE, 15 (44.) CC BY-ND 3.0 ES | UPC Barcelona, España | Didactics as a research laboratory for the improvement of 


\section{ACE Architecture, City and Environment}

Figure 4. Library in the urban structure and a new character of public space in front of the elevated Library building

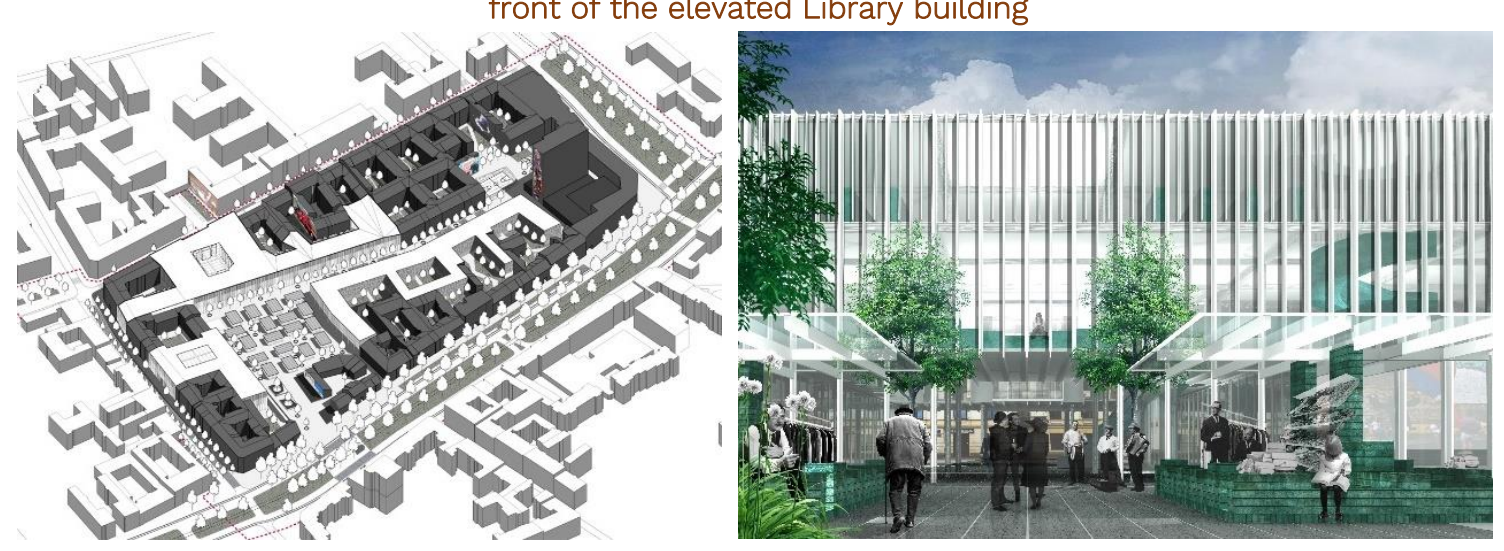

Source: Diploma project; author/student: Wojciech Szydłowski, Supervisor: Assoc. Prof. Anna Franta, D.Sc., Ph.D., Arch.; Co-Supervisor: Bartłomiej Homiński, Ph.D., Arch.

Completely different location-related conditions determined the design pursuits in terms of the role of the library in generating the thus far non-existent public space.

Railway areas located in inner cities, similarly to military grounds and other areas crucial for the national security and defense, often constitute a serious urban barrier, breaking the continuity of the urban tissue (Dudzic-Gyurkovich, 2018). In the Polish planning system railway areas fall under spatial development, which has been the competence of local authorities only since 2010 (Korpetta, 2015). For this reason, many railway areas are just an empty spot in local spatial development plans, which means that no decisions as to their future spatial form have been made yet. Furthermore, there is no concept of the storey ownership in the Polish law (Majczak, 2019), which would allow third parties to develop areas above or below non-transferable plots, in particular above the road and rail infrastructure.

As regards areas located to the north from the historical centre of Bielsko-Biała ${ }^{4}$, in the vicinity of the main railway station the width of the railway area belt is ca. $150 \mathrm{~m}$, with more than ten railway tracks. The strong impact of the barrier, which the railway line certainly is, is additionally strengthened to the west by the meridional course of the main entrance road to the city from the north. Cross links (with the exception of the area of the historic inner city) are few and do not cater for pedestrians' needs. An exception in this respect is a 250-metre-long footbridge. It constitutes a pedestrian route that links in a collision-free way the coach station and the district located in the western part of the city with the edifice of the railway station and platforms and areas located to the east from the railway tracks. These post-industrial areas are a legacy of the former economic glory of the city, which used to be a well-known centre of the textile industry, nearly completely absent now. Today, the buildings of former factories house warehouses and offices of different businesses, but according to the study of spatial development conditions and directions relating to these areas, they are classified as a city centre zone, with the concentration of centre-forming functions and the residential function, elimination with onerous services and, more importantly, arrangement of public spaces to the highest standard.

${ }^{4}$ Bielsko-Biała, a medium-sized city in the south of Poland, population above 170 thousand, an important centre of administration and industry.

ACE, 15 (4.4) CC BY-ND 3.0 ES | UPC Barcelona, España | Didactics as a research laboratory for the improvement of 10 the structure of historical inner cities. DOI: http://dx.doi.org/10.5821/ace.15.44.9197 
The site in question constitutes the location of a diploma design entitled "The Bridge of Used Time. Activation of Industrial and Railway Areas in Bielsko-Biała"5 (Figure 5). Regarding the existing footbridge over the railway areas as a necessary solution, albeit absolutely insufficient in programme-related and spatial terms, the project proposed significant extension of the existing bridge following the example of living bridges and linking it with a number of existing and proposed buildings and public spaces. The bridge in this proposal constitutes a closed, heated structure, equipped with the basic services improving the comfort of the travel experience. The axis of the bridge is lined by a modernised coach station, a tourist hotel, and a new edifice of the railway station with a waiting room suspended above the platforms on the western side, and an edifice of a new public library on the eastern side. The bridge along with the functions referred to above can be a place of the first contact with the city for visitors; it can be an attractive waiting space for students and workers commuting to the city to study or work; finally, it can also serve as a public space for permanent residents of the city. The location of the library on the eastern - worse - side of the railway tracks anticipates and catalyses the process of functional transformations of this part of the city. The programme of the public library is extended considerably and it covers a conference centre, large exposition spaces, workshops, separate zones for children and teenagers, a reading room, and a free-access zone with seats.

Figure 5. "Bridge of Used Time" with the Library as a connector of bridge public space and new square as a local center of post-industrial district

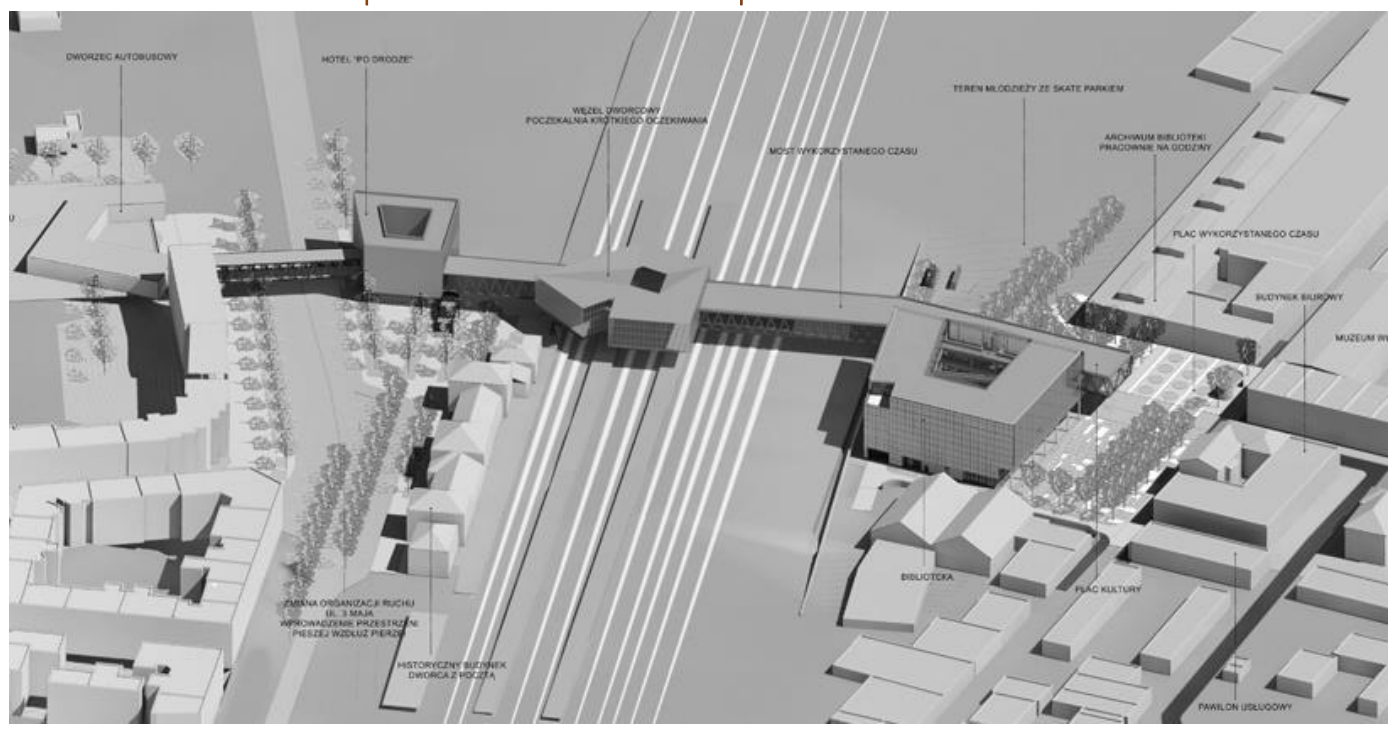

Source: Diploma project; author/student: Aleksandra Płaczek, Supervisor: Assoc. Prof. Anna Franta, D.Sc., Ph.D., Arch.; Co-Supervisor: Bartłomiej Homiński, Ph.D., Arch.

In this case the research hypothesis assumed that it is possible to eliminate the negative impact of an urban barrier constituted by the railway areas and to launch a renewal of run-down industrial areas through the improvement of the existing footbridge, completing it with a desirable programme accompanying the travelling experience, as well as improvement and boosting the legibility of the public space network on both ends of the footbridge, with a functionally open library as the major generator of changes. The proposal presented herein proves that railway areas in city centres are not just an urban barrier; they can become helpful in solving local spatial conflicts. The verification carried out within the scheme of the project is also an argument supporting the introduction of the concept of storey ownership to the Polish legal order, which has been a subject of a prolonged discussion.

${ }^{5}$ Author: Aleksandra Płaczek, Supervisor: Assoc. Prof. Anna Franta, D.Sc., Ph.D., Arch.; Co-Supervisor: Bartłomiej Homiński, Ph.D., Arch.; academic year 2016/2017.

ACE, 15 (4.4) CC BY-ND 3.0 ES | UPC Barcelona, España | Didactics as a research laboratory for the improvement of the structure of historical inner cities. DOI: http://dx.doi.org/10.5821/ace.15.44.9197 


\subsection{Post-industrial areas in the vicinity of historical centres - potential for new relationships}

The issue of neutralising the urban barrier of railway areas by new culture-forming public space that is discussed above is associated with yet another problem by signalling some aspects thereof. It is a problem of approaching the restructuring of former industrial grounds situated in a direct vicinity of historical centres. Industrial areas, which used to be located on the outskirts of cities, today constitute an integral part of the inner city structure, albeit as post-industrial areas.

Numerous countries have considerable accomplishments in transforming such areas (Kapp, Armstrong, 2012). And these accomplishments constitute an excellent base for examining good practices in terms of functional and spatial solutions, as well as the strategy of restructuring measures adopted. In Poland the implementation practice in this respect is not equally common. More importantly, there is no relevant systematic approach: comprehensive visions and strategies that would apply to the transformation of a specific area and create its new qualitative relationship with the historical structure of the city (Jarczewski, 2009).

One can speak of a certain delay in this respect as compared to the situation beyond the Polish borders. However, this situation allows to keep investigating and searching for optimal ways of using the potential of post-industrial structures in the development of new typologies of urban systems. It is hypothesised if and how the characteristic technological urban system, typical for a specific industry, can be used in the process of creating new types of public space. This problem also relates to identifying a way of developing post-industrial areas that would search for and create another sense of urbanity, complementary towards historical inner cities (Franta, 2019 a, b). It is a research area for which preceding or simultaneous studies in the form of design simulations seem to be of key importance.

In the cases presented herein so far the designing process in the didactic laboratory was an illustrative one: it demonstrated how to materialise, articulate the results and guidelines obtained in scientific research and how to verify them by means of a design proposal.

The designing process conducted in the didactic laboratory is at the same time a research process towards post-industrial areas. Initially, the research focuses on multifaceted insights into the existing state and on the determination of its inherent potential. Before the proper design works commence, it is also crucial to thoroughly analyse adequate implementations included in the good practice body referred to above. This constitutes a foundation for the search of new spatial and functional solutions, in different scales and with different degree of detail.

The ideological concept of the restructuring of former iron and steel works in Chorzów ${ }^{6}$, Upper Silesia, is depicted here as an example of such measures ${ }^{7}$ (Figure 6, 7). This example seems to represent in a very legible way the past industrial relationship with the historical city centre, as well as the postulated post-industrial one, inspired by the concept of a post-industrial city of culture and knowledge.

6 Chorzów, a medium-sized city in the south of Poland, population above 100 thousand, an important former centre of steel industry and coal mining.

7 M.Sc. diploma dissertation at the Faculty of Architecture, CUT, author/student: Anna Szafranowicz, Supervisor: Assoc. Prof. Anna Franta, D.Sc., Ph.D., Arch. One of a number of diplomas devoted to restructuring of different kinds of post-industrial inner city areas, developed under this supervision as research constituting the foundation for deliberations presented in a nearly completed book.

ACE, 15 (4.4) CC BY-ND 3.0 ES | UPC Barcelona, España | Didactics as a research laboratory for the improvement of 12 the structure of historical inner cities. DOI: http://dx.doi.org/10.5821/ace.15.44.9197 


\section{ACE Architecture, City and Environment}

E-ISSN 1886-4805

Figure 6. Post-industrial area as a new compositional heart of 3 city districts

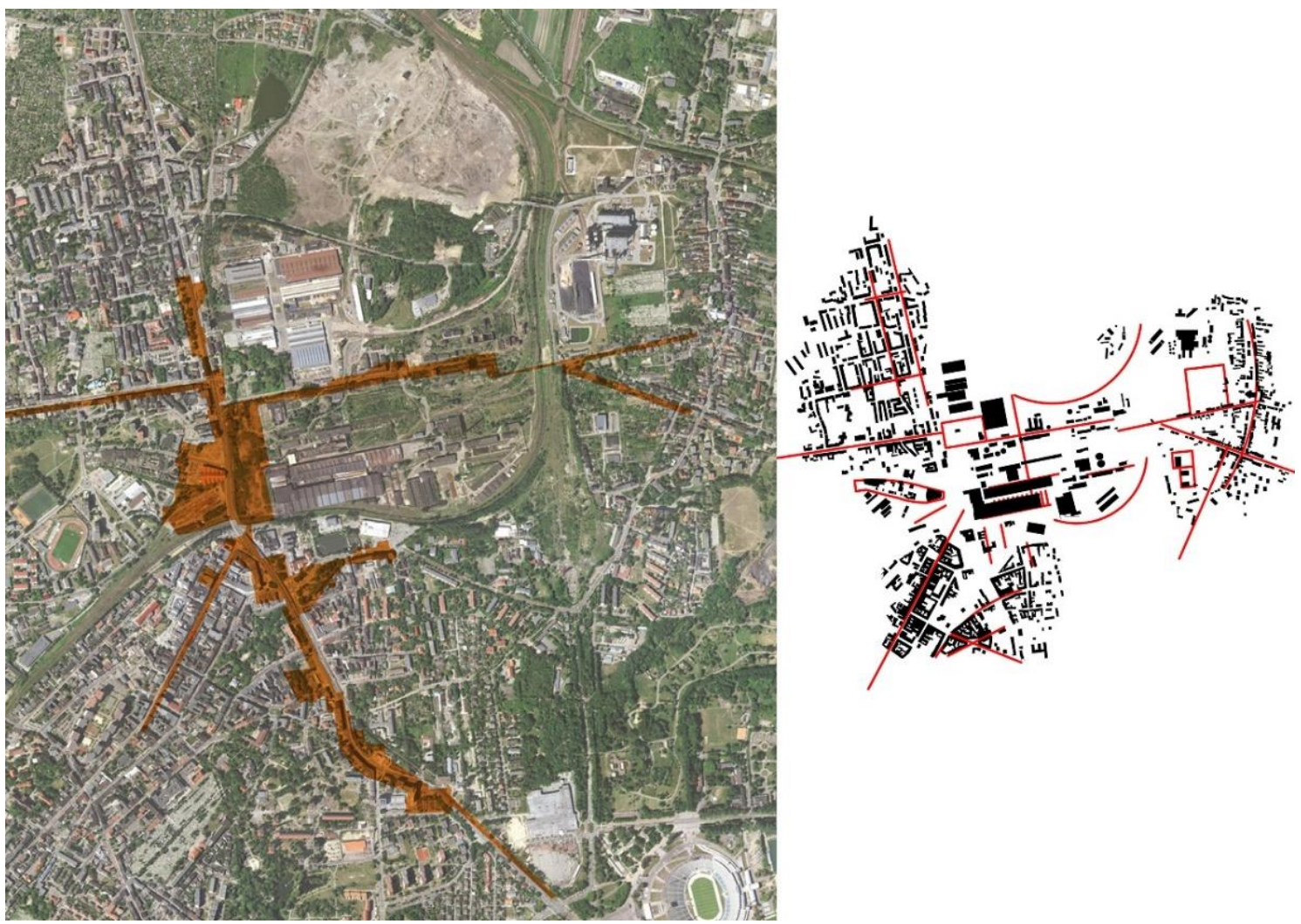

Source: Diploma project; author/student: Anna Szafranowicz, Supervisor: Assoc. Prof. Anna Franta, D.Sc., Ph.D., Arch.

The steelworks, established in the early $19^{\text {th }}$ century, became a key citygenic factor for a former settlement associated with the mining industry. The development of the city - of its three structural parts - was subordinated to the metallurgical plant. The city's architecture was to serve this huge employer, and the urban layout, with the steelworks in its very heart, emphasised their role: that of a spatial dominant and a nurturing heart of the town.

The market square, the main public utility facilities, and representational buildings were located in a legible relationship with the steelworks gates. Such principles of mutual relations persevered until then 1990s. The collapse of the steel industry meant that the heart of the town stopped beating. All that was left was a hole - a degraded area, still centrally located, but gradually becoming empty and losing the former icons of its industrial heritage. This condition continues to this day.

The restructuring concept looks for compositional relationships hidden in the structure of the three parts of the city as well as in the structure of the steelworks, and it builds new spatial and functional relations on their legibility. On the basis of transformations and adaptations of post-industrial structures, unique in terms of their scale and form, a new identity of the heart of the city is created - a pro-eco district of culture and knowledge of regional rank. The rationality of this vision is supported by the strengthening of pedestrian links with the surrounding structure of the city and by making use of the potential of the existing infrastructure of rail public transport, which makes this area accessible in the scale of the agglomeration. This vision is also associated with the concept of restoring the Silesian tradition of film industry.

ACE, 15 (4.4) CC BY-ND 3.0 ES | UPC Barcelona, España | Didactics as a research laboratory for the improvement of the structure of historical inner cities. DOI: http://dx.doi.org/10.5821/ace.15.44.9197 


\section{ACE Architecture, City and Environment}

E-ISSN 1886-480-5

Figure 7. Post-industrial area as a new district of culture and knowledge in interactive relationship with historical main city market

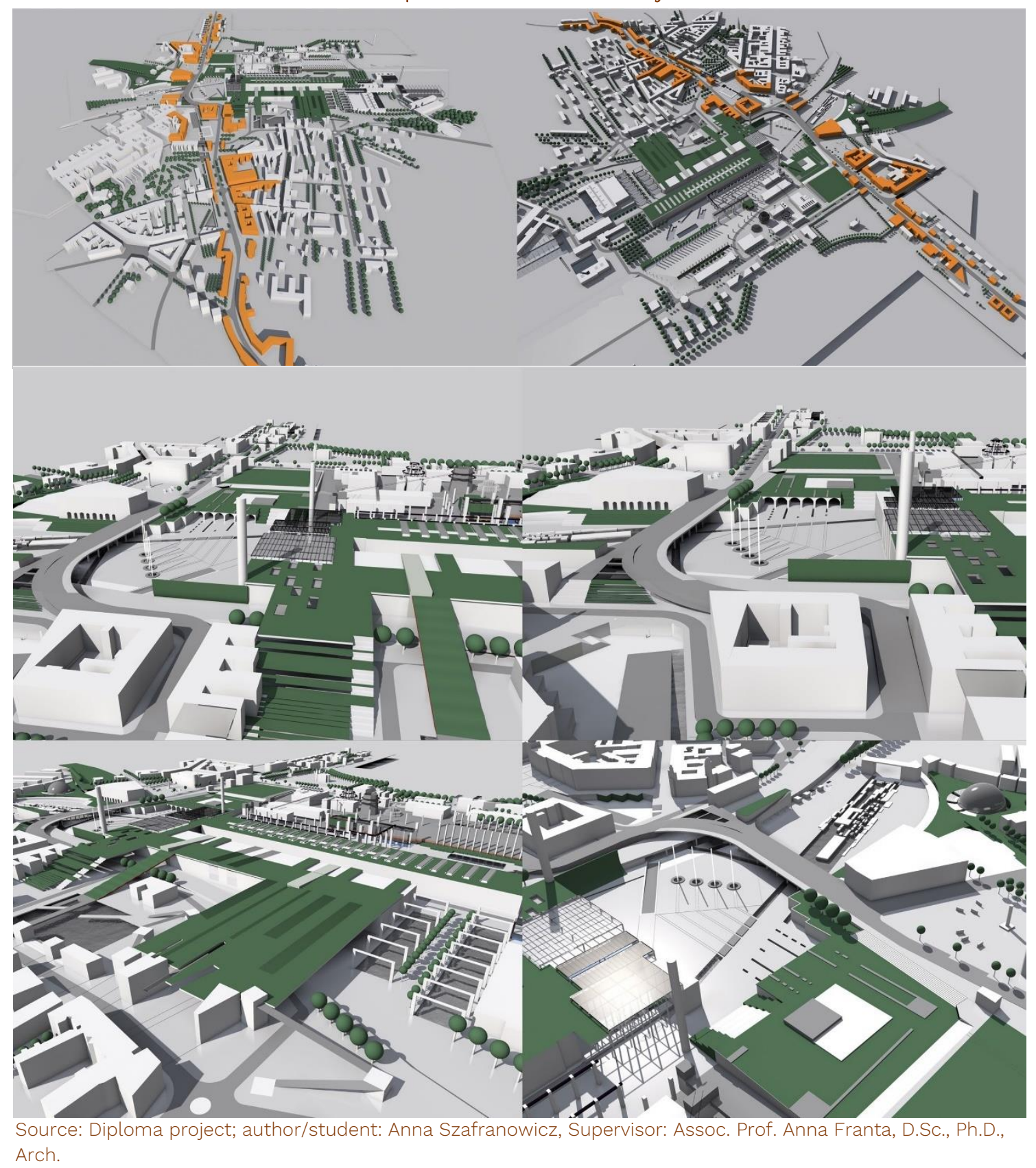

\section{Conclusions}

Each scientific discipline has research tools at its disposal that are appropriate for it. It seems that for architecture the research procedure checking by design is one of the principal ones.

Summing up the relationship between the conducted research devoted to the challenges faced by broadly understood historical inner cities and the didactic laboratory, one needs to conclude that the design results obtained in the teaching process can be regarded as data for analysis. 
Variants of ideological designing concepts relating to a specific task allow to apply the tool of comparative analysis. They offer an opportunity to compare consequences of a specific solution for the city structure - hence their usefulness in the process of optimising measures to be undertaken. For the architect-researcher-teacher, they also constitute a certain implementation simulation of theses and conclusions drawn from the research, helpful for their verification. When acting as an expert, the architect-researcher-teacher can use them as an interesting material illustrating directions of possible solutions.

A large-scale in-depth design study conducted in a polemic dialogue with the planning provisions in force can already be a fully-fledged verification of the theses posed in the research process, particularly when such a verification refers to several diversified locations illustrating the same problem (e.g. restructuring of post-metallurgical areas).

The adopted method of regarding a didactic process as a useful research tool results in enriching the research methodology, especially when it is difficult to support the subject matter thereof with the architect-researcher-teacher's own design and implementation practice, like it is the case with urban planning issues.

This tool supports ongoing scientific studies in terms of developing strategies, providing them with an opportunity to confront the conceptual approach with the implementation practice, and investigating causes of any discrepancies. For already completed studies, on the other hand, this tool allows for simulations of implementing study results, thus providing material useful for their improvement and development in subsequent scientific studies.

The author's experiences presented in this paper prove that a properly oriented didactic process in urban planning and architecture allows to effectively test and verify research hypotheses posed by an architect-researcher-teacher. This way the scientific discipline of architecture can be enriched, always with the aspect of designing being of key importance for it.

Considering the constantly growing challenges faced by broadly understood historical inner cities, including improvement of their structure, local governments - which frequently do not have adequate resources - will expect substantive support. Simulations and design proposals developed in the didactic laboratory, often experimental and quite bold in character, can be used by local authorities and open the field for further debates, conducted not only amongst professionals and scientists, but also with the participation of local residents. This need is real, which is visible in the cooperation between local authorities and schools of architecture, more and more often undertaken upon the initiative of the former.

For an architect-researcher-teacher who initiates and conducts the didactic process structured this way, the experience gained enriches also their own skills and expands their creative potential. Investigating an entire array of solutions by supervising numerous designs following the same guidelines at the same time becomes a growing bank of possibilities embedded in the awareness of the author. And should a need arise, it allows them to propose unique solutions, which have already been verified in the conditions of the academia.

It is the role of the Architecture Academia to identify problems, investigate them, and examine the potential for solving them in mutually interrelated processes: the scientific and research process, and the didactic and creative one.

ACE, 15 (44) CC BY-ND 3.0 ES | UPC Barcelona, España | Didactics as a research laboratory for the improvement of 


\section{Authors' contribution}

All authors have developed the whole article jointly as a research as well didactic cooperation within Institute of Urban Design, Faculty of Architecture, Cracow University of Technology.

Conflict of Interest: The authors declare no conflict of interests.

\section{Bibliography}

Bonet Peitx, I. (2017). Innovative architecture for the contemporary library. BiD: textos universitaris de biblioteconomia i documentació, 38. DOI: https://dx.doi.org/10.1344/BiD2017.38.4

Brenner, J. (2005). Urban redevelopment culture - changing paradigms in urban development. In G. Langenbrinck (Ed.), Work Place City. Perspectives of an Urban Redevelopment Culture (pp. 40-51). Berlin, Germany: Jovis, Edition Bauhaus.

Bryx, M., Jadach-Sepioło, A. (Eds.). (2009). Rewitalizacja miast w Niemczech, vol. 3, series: Rewitalizacja Miast Polskich. Kraków, Polska: Instytut Rozwoju Miast.

Bullivant, L. (2005). David Adjaye: Idea Store. Domus, 886, 33-51.

Busquets, J. (2006). Urban Composition: City Design in the 21st Century. In A. Graafland (Ed.), Crossover: Architecture / Urbanism / Technology (pp. 494-504). Delft School of Design Series on Architecture and Urbanism. Rotterdam, Netherlands: 010 Publishers.

Cody, J. \& Siravo, F. (Eds.) (2019). Historic Cities: Issues in Urban Conservation. Los Angeles, USA: Getty Conservation Institute.

Degórska, B., Baścik, M. (Eds.). (2013), Środowisko przyrodnicze Krakowa. Zasoby - Ochrona Kształtowanie. Kraków, Polska: IGiGP UJ.

Dudzic-Gyurkovich, K. (2018). Public space and urban barriers in Cracow. Analysis of the existing state. Technical Transactions, 115(1), 19-34. DOI: https://dx.doi.org/10.4467/2353737XCT.18.002.7953

Dymnicka M. (2008). Fragmentaryzacja przestrzeni publicznej - próby rekompozycji: Studia Regionalne i Lokalne, No. 3(33). Retrieved from http://www.studreg.uw.edu.pl/pdf/2008 3 dymnicka.pdf

Fitch, J. et al. (2011). Valuación de la producción y organización territorial: Una modelación hedónica: San Nicolás de los Garza, México. In Proceedings of the 7th International Conference on Virtual Cities and Territories (p. 71-74). Barcelona, España: CPSV. DOI: http://dx.doi.org/10.5821/ctv.7697

Franta, A. (2004). Reżyseria przestrzeni: o doskonaleniu przestrzeni publicznej miasta. Kraków, Polska: Publishing House of the Cracow University of Technology.

Franta, A. (2019a). Search of the Quality of City Public Space. Space Directing - Tool of improvement. IOP Conference Series: Materials Science and Engineering, 471, 1-9. DOI: https://doi.org/10.1088/1757899X/471/9/092029

Franta, A. (2019b). Myths and Realities of Adaptable city. Contemporary City as Adaptable Hybrid. IOP Conference Series: Materials Science and Engineering, 471, 1-10. DOI: https://doi.org/10.1088/1757$\underline{899 \times / 471 / 9 / 092030}$

ACE, 15 (4.4) CC BY-ND 3.0 ES | UPC Barcelona, España | Didactics as a research laboratory for the improvement of 16 the structure of historical inner cities. DOI: http://dx.doi.org/10.5821/ace.15.44.9197 
Franta, A. \& Dudek M. (2017). Concept of Smart City as the Search of Contemporary Meaning of Urbanity upon the Example of the Revitalisation of the Grounds of Former Belval Steelworks in Luxembourg. Środowisko Mieszkaniowe - Housing Environment, 21, 131-139. DOI: https://doi.org/10.4467/25438700SM.17.077.7934

Górski, A.S. (2015). Problemy planistyczne w odniesieniu do obszarów kolejowych na przykładzie Kielc. In J. Liro, M. Liro, P. Krąż (Eds.). Wspótczesne problemy i kierunki badawcze w geografii. Tom 3. Kraków, Polska: IGiGP UJ.

Gronostajska, B. (2007). Kreacja i modernizacja przestrzeni mieszkalnej. Teoria i praktyka na przyktadzie wybranych realizacji wroctawskich z lat 1970-1990. Wrocław, Polska: Publishing House of the Wroctaw University of Science and Technology.

Gyurkovich, J. (2010). Architektura w przestrzeni miasta: Wybrane problemy. Kraków, Polska: Publishing House of the Cracow University of Technology.

Gzell, S. (2015). Wykłady o wspótczesnej urbanistyce with English Supplement on Contemporary Town Planning. Warszawa, Polska: Publishing House of the Warsaw University of Technology.

Homiński, B. (2011). The impact of contemporary civilization transformations on the new role of libraries in the city structure (Doctoral thesis, supervisor: Palej, A.), Cracow University of Technology, Kraków.

Homiński, B. (2019). Architectural spaces of libraries in the expectations and opinions of the librarians of Krakow's public libraries. IOP Conference Series: Materials Science and Engineering, 471, 1-10. DOI: https://doi.org/10.1088/1757-899X/471/7/072015

Hvenegaard, C. \& Jochumsen, H. (2009). The Fall and Rise of the Physical Library. Paper presented at The 17th BOBCATSSS Symposium. Porto, Portugal. Retrieved from http://eprints.rclis.org/bitstream/10760/12946/1/40.pdf

Jarczewski, W. (Ed.). (2009). Przestrzenne aspekty rewitalizacji śródmieścia, blokowiska, tereny poprzemystowe, pokolejowe i powojskowe, vol. 4, series: Rewitalizacja Miast Polskich. Kraków, Polska: Instytut Rozwoju Miast.

Jeżak, J.; Nejman, M. Wierzchowski M. (2011). Wielokryterialna analiza dziewiętnastu osiedli zabudowy blokowej położonych na terenie Gminy Miejskiej Kraków. Kraków, Polska: Instytut Rozwoju Miast.

Jeżak, J. et al. (2006). Strategie rehabilitacji blokowisk, Kraków, Polska: Instytut Rozwoju Miast

Kapp, P.H. \& Armstrong, P.J. (Eds.) (2012). SynergiCity: reinventing the postindustrial city. Urbana, USA: University of Illinois Press.

Kovác, Z. \& Herfert, G. (2012). Development Pathways of Large Housing Estates in Post-socialist Cities: An International Comparison, Housing Studies, 27(3), 324-342, DOI: https://doi.org/10.1080/02673037.2012.651105

Kruszewski, T. (2012). Przestrzenie biblioteki: o symbolicznej, fizycznej i społecznej obecności instytucji. Toruń, Polska: Scientific Publishing House of the Nicolaus Copernicus.

Knorr-Siedow, K. \& Droste, Ch. (2003). Large Housing Estate in Germany. Overview of development and problems in Berlin. Restate Report 2b. Utrecht, Netherlands: Utrecht University.

ACE, 15 (44.) CC BY-ND 3.0 ES | UPC Barcelona, España | Didactics as a research laboratory for the improvement of 17 the structure of historical inner cities. DOI: http://dx.doi.org/10.5821/ace.15.44.9197 
Lushington, N.; Rudorf, W. \& Wong, L. (2016). Libraries: A Design Manual. Berlin, Basel: Birkhäuser.

Majczak, P. (2019). Prezydent miasta na prawach powiatu jako zarządca dróg publicznych - na przykładzie Wrocławia. Miasto. Pamięć i Przyszłość, 3(2). DOI: https://doi.org/10.26774/mpp.84

Matusik, A. et al. (2020). Hydrourban spatial development model for a resilient inner-city. The example of Gdańsk. ACE: Architecture, City and Environment, 15(43), 9211.9 DOI: http://dx.doi.org/10.5821/ace.15.43.9211

Melvin, J. (2006), Idea Store, Whitechapel. Architectural Design, 76: 126-129. Retrieved from DOI: https://doi.org/10.1002/ad.336

Muliuolytè, J. (2013). Rediscovering Large Scale Housing Estates in Post Socialist Cities: Journal of Architecture and Urbanism, Volume 37(1), 51-58, DOI: https://doi.org/10.3846/20297955.2013.781180

Mumford L. (1970). The Culutres of cities. San Diego, New York: A Harvest / HBJ Book.

Murzyn-Kupisz, M. and Działek, J. (2013). Cultural heritage in building and enhancing social capital. Journal of Cultural Heritage Managements and Sustainable Development 3(1), 35-54. https://doi.org/10.1108/20441261311317392

Murzyn-Kupisz, M. and Działek, J. (2015). Libraries and Museums as Breeding Grounds of Social Capital and Creativity: Potentials and Challenges in the Post-Socialist Context. In S. Warren, P. Jones. (Eds.). Creative Economies, Creative Communities (pp. 145-169). London, England: Routledge.

Musterd, S. (2004). Amsterdam as a Creative Cultural Knowledge City: Some Conditions. Built Environment, 30(3), 225-234 DOI: https://doi.org/10.2148/benv.30.3.225.54307

Nasr, S.H. (2001). The Spirit of the Cities. In J. Cody, F. Siravo (Eds.) (2019), Historic Cities: Issues in Urban Conservation (pp. 16-21). Los Angeles, USA: The Getty Conservation Institute.

Niegaard, H.; Lauridsen, J. \& Knud, S. (Eds.). (2009). Library Space. Inspiration for Buildings and Design. Denmark: Danish Library Association.

Palej A. \& Homiński B. (2007). Contemporary libraries and their new role in the lives of city dwellers. Technical Transactions, 104(z. 2-A), 207-214.

Rembarz G. (2009). Wielkie osiedle mieszkaniowe drugiej połowy XX wieku w kontekście strategii reurbanizacji: Osiedle: reurbanizacja, Urbanistyka. Międzyuczelniane Zeszyty Naukowe, Warszawa, 3383.

Romero, S. (2008). Library Architecture. Recommendations for a Comprehensive Research Project. Barcelona, Spain: COAC.

Rowlands, R., Musterd, S. \& Van Kempen, R. (Eds.). (2009). Mass Housing in Europe: Multiple Faces of Development, Change and Response. Basingstoke, UK: Palgrave Macmillan.

Schittich, Ch. (2005). Libraries in the Age of Digital Information. Detail, 3, 246.

Sidorek, D. (2009). Bazar Różyckiego: Mit targowiska w ujęciu antropologicznym. Konteksty 01-02, 106130.

ACE, 15 (44.) CC BY-ND 3.0 ES | UPC Barcelona, España | Didactics as a research laboratory for the improvement of the structure of historical inner cities. DOI: http://dx.doi.org/10.5821/ace.15.44.9197 
Spiridonidis, C. \& Voyatzaki, M (2017). The gifts of Prometheus. Profiling architectural education in a fast-changing world. ACE: Architecture, City and Environment, 12(34), 165-178. DOI: http://dx.doi.org/10.5821/ace.12.34.5286

Szczerek, E. (2017). The role of revitalization of housing estates in creating continuity and complementarity of the public spaces in the contemporary city (Doctoral thesis, supervisor: Franta, A.), Cracow University of Technology, Kraków.

Szczerek, E. (2018). Rewitalizacja osiedli wielkopłytowych a ciągłość i komplementarność przestrzeni publicznej miasta. Kraków, Polska: Publishing House of the Cracow University of Technology.

Szczerek, E. (2019). The Loss of Potential: Large-Panel Housing Estates - Czyżyny Case. IOP Conference Series: Materials Science and Engineering, 471, 1-10. DOI: https://doi.org/10.1088/1757$\underline{899 X / 471 / 9 / 092034}$

Van Kempen, R., Dekker, K., Hall S., Tosics, I. (Eds.). (2005). Restructuring Large Housing Estates in Europe. Bristol, UK: Policy Press.

Van Winden, W. (2010). Knowledge And The European City: Tijdschrift voor Economische en Sociale Geografie, Royal Dutch Geographical Society KNAG, 101(1), 100-106. DOI: https://doi.org/10.1111/j.1467$\underline{9663.2009 .00591 . x}$

Węcławowicz-Gyrukovich, E. (2013). Architektura najnowsza w historycznym środowisku miast europejskich. Kraków, Polska: Publishing House of the Cracow University of Technology.

ACE, 15 (44.) CC BY-ND 3.0 ES | UPC Barcelona, España | Didactics as a research laboratory for the improvement of 